\title{
A középfokú képzés területi rendszerének változása és továbbfejlesztése
}

\section{Changes and development in the framework of regional secondary vocational education in Hungary}

\author{
VELKEY GÁBOR
}

KULCSSZAVAK: közoktatás, szakképzés, területi összehangolás, térségi integrál† szakképző központok, TISZK

ABSZTRAKT: A középfokú képzés területi rendszerét a szabályozás rendszerváltás utáni immár húsz éves történetében mindössze egyetlen alkalommal, a térségi szakképző központok létrehozásakor (2007) próbálták tudatosan alakítani. A jogszabályok módosítása óta eltelt időszak vizsgálati tapasztalatai alapján és a kormányzat tervezett intézkedéseit látva kijelenthetjük, hogy sajnos ez a kétségkivül elöremutató kísérlet több ok miatt is kudarcot vallott. A célok helyességét (a szakképzés képzésmódszertani megújítása, racionális csoport- és intézményszervezés - elsősorban a szétaprózottság megszüntetése érdekében -, területi összehangolás, érdemi infrastruktúra-fejlesztés, a fejlesztési források hatékony felhasználása) egyértelműen megerősítve, vizsgálataim alapján az átalakitás sikertelenségét abban foglalhatóm össze, hogy

- nem változtak meg a múködést érdemben meghatározó finanszírozási és érdekeltségi mechanizmusok,

- a szervezeti keretekre vonatkozó szabályozás szervezeti anarchiát eredményezett,

- a formális szervezeti struktúrák mögött tovább élhetett a meghaladni kivánt képzési és szervezési gyakorlat,

- a területi összehangolásban és a munkaerő-piaci megfelelésben kulcsszerepet betöltő regionális fejlesztési és képzési bizottságok egyrészł a politika, másrészt az intézményi és területi vagy szakmai (szakképzési) lobbik zsákmányszerzését szolgálta.

E feltárt problémák rendezése érdekében tanulmányom zárófejezetében hét pontban konkrét javaslatot teszek a rendszer megújításának legfontosabb irányaira.

KEYWORDS: public education, vocational education, regional harmonisation, Regional Integrated Vocational Training Centre

ABSTRACT: The regulations concerning the framework of regional secondary vocational education were left largely untouched in the over twenty years following the change of the political system. Major and systematic changes were first introduced in 2007 with the

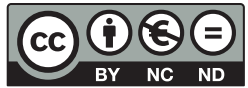


creation of regional integrated vocational training centres (a.k.a. TISZKS).

The establishment of these institutions was without doubt a great leap forward, but in view of planned government provisions and the experiences gained from monitoring practices put in place since the modification of the regulations, it seems that they failed to achieve their aim.

Without questioning the soundness of purpose of the modifications (i.e. renewal of the methodology of vocational training, streamlining the organisation of institutions and units of students - principally for the sake of avoiding the fragmentation of institutions -, substantive innovation in terms of the infrastructure used, effective use of financial resources available for the purpose of development), our study identifies the following reasons for their lack of success:

The mechanisms of financing and the structures of interests that govern the functioning of the field have remained unchanged.

The rules adopted in the modified regulations regarding organisational matters led in their general approach to organisational anarchy.

Thus, although the formal structures changed, the old organisation and its ineffective methods of training survived in practice.

The committees entrusted with the task of regional harmonisation and of assuring that vocational training matches the needs of the labour market (RFKTs) became dominated by political, institutional and regional or professional lobbies and infested with the corruption that comes with them.

In the closing chapter of our study we offer seven specific recommendations aimed at a successful adjustment and renewal of the system of vocational secondary education.

A középfokú képzés területi rendszerét a szabályozás rendszerváltás utáni történetében mindössze egyetlen alkalommal, a térségi integrált szakképző központok (TISZK) létrehozásakor próbálták tudatosan alakítani. A jogszabályok módosítása óta eltelt időszak vizsgálati tapasztalatai alapján és a kormányzat formálódó terveit látva azonban úgy tűnik, hogy e kétségkívül előremutató jövőképet jelentő kísérlet - több ok miatt is - kudarchoz vezet.

A TISZK-ek létrehozásának terve európai tapasztalatok alapján, a Nemzeti fejlesztési terv I. szakaszában, a Humán erőforrás operatív programban fogalmazódott meg, aminek eredményeként az országban tizenhat központ fejlesztése indult el. A projektek célja érdemi tartalmi és infrastruktúra-fejlesztés volt, továbbá a mérethatékonyság, a racionálisabb csoportszervezés, a gazdasági kapcsolatok elősegítése és a fejlesztési források hatékonyabb felhasználása érdekében a szétaprózott szakképzési intézményrendszer nagyobb egységekbe történő újraszervezését is elő kívánta segíteni (Balázs, Palotás, 2006, Velkey 2010). A projektek 2005-2006-ban indultak, a képzőhelyek fizikai kialakítását is magában foglaló fejlesztőszakasz 2006-2007-ben folyt, a végleges lezárás pedig többnyire 2009-re csúszott. A hatalmas érdeklődésre hivatkozva még a projektek végleges lezárása előtt megszületett a döntés a modellnek a hazai szakképzés egészében történő bevezetéséről, amihez a futó EU-s fejlesztési szakaszban újabb érdemi fejlesztési forrásokat is kapcsoltak. 


\section{A TISZK-modell bevezetésének jogszabályi háttere}

A jogszabályi változások ${ }^{1}$ legfontosabb eleme a „szakképzés feladatainak regionális megszervezése" című fejezet törvénybe iktatása, ami bevezette a szakképzés irányításának új, regionális szintjét a regionális fejlesztési és képzési bizottságok (RFKB) formájában, továbbá meghatározta a szakképzési intézmények együttműködésének új szervezeti formáit és a gyakorlati képzés fizikai bázisát jelentő úgynevezett központi képzőhelyet.

A szabályozás logikája - jellemző sajátosságként - nem előírta, hanem csupán lehetőségként kínálta fel a TISZK létrehozását, amit érdekeltségi alapon próbált elősegíteni a fejlesztési forrásokhoz történő hozzájutás szabályainak lényeges átalakításával. Ennek értelmében pályázati úton (Munkaerő-piaci Alap képzési alaprész központi és decentralizált része) vagy a gazdasági szereplőktől közvetlenül (fejlesztési támogatás) csak olyan TISZK-hez tartozó szakképzők fenntartói juthattak forrásokhoz, amelyeknél a nappali iskolai oktatásban részt vevő szakképzőiskolai tanulók létszáma három év átlagában eléri az ezerötszáz főt. A TISZK tehát lényegében szervezeti formában megjelenő együttműködés, ami a szabályozás alapján szorosabb és lazább is lehet. A legszorosabbat a TISZK-ként is definiált, egy intézménybe szervezett (összevont) szakképző iskola ${ }^{2}$ jelenti, aminél lényegesen lazább kapcsolat a szakképzésszervezési társulás vagy társaság ${ }^{3}$. Ez utóbbiak esetén az együttmúködésbe történő belépés feltétele, hogy az érintettek elfogadják az RFKB szakképzéssel összefüggő döntéseit, és vállalják, hogy fenntartói jogaik egy részét a társulás (társaság) közös döntéseinek rendelik alá, ami lehetővé teszi a képzési irányok, arányok és fejlesztések összehangolását. A területi folyamatokat befolyásoló fontos szabály még, hogy ha a szakképzésszervezési társulás által ellátott feladatkörök valamelyikében a feladatellátásra nem kötelezett fenntartó (települési önkormányzat) lemond a feladatellátásról, akkor azt nem a megyei önkormányzat, hanem az adott települést is magában foglaló társulás veszi át.

Az együttműködés során tehát az intézmények megmaradnak önállónak, nem változik fenntartójuk, a szakképzés szervezésének (képzési irányok, arányok, fejlesztések, megállapodások stb.) legfontosabb kérdéseiben azonban a regionális szintű irányítás új szervezetének - az RFKB-nak - utasításait figyelembe véve közösen hozzák meg a döntéseket. Az ilyen lazább kapcsolatot jelentő TISZK-ek számára a szakképzés szervezésére vonatkozó belső együttműködést segítendő, a közoktatási törvényben megjelenik a „szakmai vizsgára felkészíto iskola"4 is, amely csak szakképzési évfolyamon folytat képzést, és nemcsak saját, hanem más szakképző („küldő iskola”) tanulói számára is.

A jogszabályi változtatások kulcselme a szakképzés regionális szintű irányításában fontos szerepkörrel felruházott RFKB létrehozása ${ }^{5}$, amelynek a képzési irányok és arányok meghatározására, a decentralizált fejlesztési források felhasználására és a hiány-szakképesítésekre vonatkozó döntési, illetve a 
központi forrásokból támogatott intézményi fejlesztéseket illető javaslattételi joga lényegében azt jelenti, hogy az RFKB valódi regionális irányító- és összehangoló szerepet tölthet be a teljes iskolarendszerü szakképzés alakításában.

A jogszabályi változtatások áttekintése két fontos dologra is rámutat: egyrészt a szabályozás orientáló, érdekeltségi alapú megközelítése és a meglehetősen bonyolult megfogalmazás a teljes hazai szabályozás kimondottan bonyolult voltára utal, másrészt a módosítások önmagukban is az újraszabályozás kényszerére hívják fel a figyelmet, ami a rendszer diszfunkciókkal jellemezhető voltából ered. A következőkben ezeket a szabályozást kiváltó diszfunkciókat igyekszem röviden áttekinteni.

\section{Szétaprózódott intézményrendszer, párhuzamos fejlesztések, esetleges munkaerö-piaci kapcsolatok}

A jogszabályi változtatások ismertetésekor említett ezerötszáz fős létszámhatár egyértelműen arra utal, hogy a jogalkotó a szakképző intézmények együttmüködését a nagyobb szervezési egységek létrehozásának érdekében szorgalmazza. A szétaprózódott intézményszerkezet több összetevő hatására vált valóban jellemzővé a hazai iskolarendszerű szakképzésben.

A rendszerváltás után a középfokú iskolarendszert érintő három legfontosabb változás a rendhagyó szerkezetü (többnyire egyházi) gimnáziumok és a vegyes (többcélú) szakképző intézmények elterjedése, továbbá a közismereti és szakmai képzés szétválasztása volt. A rendszerváltás előtti középfokú intézményrendszer tiszta profilú szakmunkásképző intézményekből (vagy szakiskolákból), szakközépiskolákból és gimnáziumokból állt, a szakképzés a közismereti képzéssel párhuzamosan folyt, és az intézmények a „szocialista” gazdaság szerkezetéhez igazodva, ágazati alapon különültek el. A rendszerváltással értelemszerüen együtt járó szemléletváltás az oktatásban a kívülről irányított pályaválasztással szemben az egyén döntési autonómiájának, a választás valódi szabadságának igénylésében jelent meg. A szülő és a tanuló választani akart; elsősorban perspektívát, konkrétabban sikerrel kecstető szakképzettséget, még konkrétabban az ahhoz jó lehetőséget biztosító középiskolát. A választás pedig értelemszerüen versenyt jelent, a rendszerváltás evidens következményeként így a közoktatásban is egyértelműen erősödött és élesedett a verseny, amely egyik oldalról a rendelkezésre álló iskolai férőhelyekért folyt a tanulók között. Mielőtt a verseny összetevőit elemezném, röviden igyekszem áttekinteni a versenyt meghatározó legfontosabb tényezőket; hogy mikor és milyen információk alapján történik a választás, illetve milyen lehetőségek közül lehet választani.

A választás időpontjával a tudományos közvélemény már a rendszerváltást megelőzően foglalkozott a hagyományos nyolc osztályos általános iskolai képzési rendszer felülvizsgálata során. Ennek eredményeként jelentek meg 
például a rendhagyó szerkezetű (nyolc és hat évfolyamos) gimnáziumok, és indult el több településen az úgynevezett egységes iskola ${ }^{6}$ meghonosításának kísérleti programja (Loránd 1994). A szakirodalom ugyanis mind a lemaradók, mind az átlag felett teljesítők esetén vitatta azt a szelektív intézményszervezés logikája mögött meghúzódó közkeletű vélekedést, miszerint hatékonyabban szervezhető az oktatás, ha az eltérő képességü tanulókat külön csoportba sorolják. Ezenkívül többen a szelektív mechanizmusokkal magyarázták azokat a nemzetközi összehasonlításban kiugróan nagy különbségeket, amelyek már akkor is jellemezték a hazai középfokú intézményeket. Az intézmények és az általuk nyújtott szolgáltatások közötti különbségek a jelen felé tovább nőttek, a mai helyzetet jól jellemzik azok a kutatási eredmények (Csapó 2008a), amelyek szerint a tanulók teljesítményében megfigyelhető különbségek hetven százalékáért az iskolák közötti különbségek felelősek. A nemzetközi összehasonlító iskolai méréseket elemezve Hermann (2008) ezen túl azt is kiemeli, hogy a tanulói teljesítmény szóródásában a középfokú programtípusok (szakiskola, szakközépiskola, gimnázium) közötti különbségek a döntő jelentőségűek.

A szakképzés szervezésében a rendszerváltás után bevezetett leglényegesebb változtatás a korábban párhuzamosan folyt közismereti és szakmai képzés szétválasztása volt (Benedek 2003), amivel egyszerre célozták a szakmai képzési idő lerövidítését, a szakképzés választásának magasabb életkorra tolását és a hatékonyabb képzésszervezést. $\mathrm{E}$ célok a pályaválasztás megalapozottságát, a képzések költséghatékonyságát és munkaerő-piaci illeszkedését elősegítve valóban érdemi előrelépéssel kecsegtettek. Mielőtt azonban felmenő rendszerben valóban bevezették volna ezeket, 1996-ban már módosították az éles szétválasztást kimondó szabályokat, lehetőséget teremtve a közismereti képzés szakaszában szakmai előkészítő ismeretek nyújtására. A módosítás egyrészt az átmenet foglalkoztatási nehézségeinek kezelését szolgálta (szakoktatók óraadási lehetősége a közismereti szakaszban), másrészt a szakképzési szakasz megkezdéséhez „feltolt” szakmaválasztás megalapozását segítette az érdeklődés felkeltésével és a szükséges képességek feltárásával. Azzal a jogszabályi kitétellel azonban, amely szerint e képzési elemek beszámíthatók a szakképzésbe, nemcsak jelentősen kibővült az intézmények mozgástere, hanem szinte korlátlan lehetőséget kaptak a saját érdek érvényesítésére. Ha ugyanis szakmai előkészítés címén a végzettséghez szükséges tartalmat oktatnak, akkor az beszámítva lecsökkentheti a képzési időt, amivel visszacsempészhetővé válik a párhuzamos szakképzésszervezés. ${ }^{7} \mathrm{Az}$ időben előbbre kerülő végzettség megszerzése egyrészt vonzó lehet a diákok számára, másrészt azonban lecsökkenti a szakképzés megkezdése előtti átjárhatóságot, és akadályozza a pályaválasztás magasabb életkorba történő feltolását is, hiszen a tanuló a korábban teljesített modulok miatt nem érdekelt a szakképzés formális megkezdésekor az át- vagy kilépésben. Mindez szorosan visszahat a szakképzési szakasz csoportszervezésére. Az előképzettekkel ugyanis nem „keverhetők” a kívülről jövők, és miután az intézmény a saját tanulói felé a ta- 
nulói jogviszonnyal a szakképzésre is „leszerződött”, az ő továbbvitelük jogi kényszer, ami csökkenti a csoportok méretét, így rontja a hatékonyságot, és szétaprózottságot eredményez. A fejkvóta alapú finanszírozás rendszere és a csökkenő normatívák tehát szinte öngerjesztően a tanulók minél nagyobb arányának továbbvitelében teszik érdekeltté az intézményeket, ezzel tovább akadályozva a szakképzési szakasz megkezdésekor az átjárhatóságot és erősítve a párhuzamos képzésszervezést, csakhogy immár nem a rendszerváltás előtti három- és négyéves, hanem négy- és hatéves ciklusban. ${ }^{8}$

A saját tanulóknak a szakképzési szakaszban való megtartása a szakiskolának is evidens érdeke. Itt a problémát inkább a lemorzsolódás jelenti, aminek hátterében szociális és magatartásbeli problémák állnak, eredménye pedig a teljes munkaerő-piaci ellehetetlenülés (Vámosi 2005b). Kutatási eredmények igazolják, hogy a szakiskolákban az átlagosnál sokkal magasabb, harminc százalék körüli a lemorzsolódók aránya, és a hátrányos helyzetü tanulók közel felének nem sikerül szakmai képesítést szerezni (Liskó 2008). Ezért is van különös jelentősége, hogy a lemorzsolódást ne segítse, hanem éppen korlátozza a rendszer. ${ }^{9} \mathrm{E}$ korlátozás azonban csak úgy érhet célt, ha az intézmények megfelelő eszközökkel rendelkeznek a problémák szakszerű kezelésére, ami azonban a jelen felé közeledve a romló finanszírozási feltételek miatt immár a legkedvezőbb költségvetésű megyei jogú városok és megyék iskoláiban sem biztosított. Így az intézmények részéről is növekszik a nehezen kezelhető tanulókkal szembeni türelmetlenség, és az igény, hogy a problémát okozóktól „megszabadulhassanak”.

A szakiskolákban és szakközépiskolákban egyaránt jellemzővé váló visszacsempészett párhuzamos szakképzés azzal, hogy érdemben lecsökkenti a szakképzés megkezdésekor az átjárhatóság lehetőségét, lényegében visszaállítja a rendszerváltás előtti időszakban jellemző általános iskola utáni továbbtanulás „sorsdöntő” jellegét. Ennek egyik konkrét következménye a „régi” (elit) gimnáziumok iránti erős nosztalgia, amelyeknek rendhagyó szerkezetű intézményeit még (az élesebb versenyt jelentő) nyolcadik évfolyamot követő pályaválasztást megelőzve igyekeznek tíz- vagy tizenkét éves korban biztosítani gyermekeik számára a tanulásorientált, magasabb státusú, értelmiségi családok.

A szakiskolák leépülését Kézdi (2008) szoros összefüggésbe hozza a specifikus képességeknek az általános képességekhez viszonyított egyértelmű értékvesztésével. A racionális mérlegelés előfeltétele a szükséges információk megléte, ami az általános iskola utáni „sorsdönto” pályaválasztás alapveto problémáját jelenti, hiszen a megalapozott döntéshez szükséges információk sem a gyermek képességeit, sem a képzés perspektivikusságát (elhelyezkedés, jövedelem) illetően nem állnak rendelkezésre. A középiskolai továbbtanulást meghatározó bizonyítvány és felvételi dolgozatok is szinte kizárólag a lexikális tudást mérik, de az általános iskolai képzés sem képes például a manualitást, a közösségi, szociális érzékenységet, a kommunikációs, emocionális 
képességeket a szükséges mélységben feltárni, a munkaerő-piaci esélyek pedig négy- és hatéves képzési ciklusok esetén sem jelezhetők előre. Ha kevés az információ a racionális döntéshez, akkor csupán általános képzetek alapozhatják meg a választást. Ilyen - adatokkal is igazolható - képzet a magasabb iskolai végzettséghez kapcsolódó szélesebb elhelyezkedési esély, magasabb jövedelem. Báthory népszerü tanításelméleti munkája is e tényezők fontosságára hívja fel a figyelmet; az intézményi képzések a modern társadalmakban kiválóan alkalmasak a vágyak (motiváció) és a lehetőségek (megerősítés) mozgósítására (aktivizálás) (Báthory 2000), amit leegyszerűsítve „felfelé orientálódásként" fogalmazhatunk meg (Velkey 2010). A magasabb szintű képzések tömegessé válását nemzetközi tapasztalatokra hivatkozva a szakirodalom is a demokratizálódás és szabadság evidens következményeként (Csapó 2008b.) értelmezi. Ráadásul a jelenség mindig együtt jár a tömegessé váló képzési szint leértékelődésével, presztízsének csökkenésével is, és egy még magasabb képzési szint létrejöttével, elitképzéssé válásával (Archer 1988). E folyamat az érettségit adó képzésekben már hazánkban is lejátszódott, és néhány éve felgyorsulóban van a felsőoktatás esetében (Varga 2008b).

A rendszerváltás utáni időszak szabadabb intézményválasztása természetesen érintette az intézményeket és így szolgáltatásaikat is - ami a verseny másik oldalát írja körül. Az intézményben folyó munka eredményességét alapvetően befolyásolja az oda járó tanulók felkészültsége, képessége, motiváltsága, így a férőhelyek feltöltése mellett a minél jobb tanulói összetétel elérése az intézmény érdeke, ami a demográfiai csökkenés időszakában még élesebbé teszi az intézmények tanulókért folyó versenyét (Balázs 2007).

Tehát a rendszerváltás utáni időszakban a pályaválasztást az iskolahasználók szemléletének változása mellett a tanulókért folyó élesedő versenyre adott, a képzési kínálatot alakító válaszok határozták meg. A „Kádár-rendszer" kemény szabályainak a nyolcvanas évek második felében megfigyelheto egyre gyorsuló olvadása előbb zárójelbe tette, később elsöpörte az államnak a középiskolai szolgáltatást szabályozó szerepét. Ezt az eleinte a szabadság megjelenéseként, később azonban egyértelműen szabályozási űrként értelmezhető helyzetet az államigazgatás rendszerének átalakítása után elvileg az önkormányzatok - a középfokú oktatás esetében a megyei jogú városok, a megyei önkormányzatok, a fóvárosi önkormányzat és a középfokú intézmények fenntartását vállaló további városok -, az oktatásüggyel foglalkozó minisztérium és területi szervei töltötték meg tartalommal. Az önkormányzatok oktatásirányítással kapcsolatos hatásköreit a képviselö-testületek gyakorolják, amelyek megalakulásuk után azonnal fajsúlyos döntések meghozatalára kényszerültek. A laikus, ugyanakkor változtatni akaró testületek és a teljesen elbizonytalanított szakmai irányítás együttesen a folyamatok szabad önmozgását eredményezték (Pálné 2008), ami egyrészt a korábbi mechanizmusok szinte automatikus továbbélését hozta, másrészt szabad utat adott a perspektivikusnak tetsző kezdeményezéseknek, függetlenül attól, hogy azok intézményi 
részérdekeket közvetíttek csupán, vagy valóban a képzés tartalmi megújítását szolgálták, mint például a visszacsempészett párhuzamos szakképzés.

A '90-es években mindkét irány jellemző volt. A rendszer automatikusan működött tovább, a gyerekek bekerültek az intézményekbe, a tanárok képezték őket, a még működő gyakorlóhelyek részt vettek a képzésben. Ha megszűnt a gyakorlóhely, akkor vagy átvette a tanulókat valamely másik hasonló profilú cég, vagy külső gyakorlóhely hiányában bekerültek az intézményi tanmühelybe..$^{10} \mathrm{~A}$ versenyhelyzetükön javítani akaró intézmények tehát lényegében szabad mozgásteret kaptak mind a képzési szint, mind a képzési irány változtatására, és általában éltek is ezzel, így sorozatban jelentek meg munkaerő-piaci igénnyel és gazdasági kapcsolattal nem alátámasztott divatos vagy azzá tehető képzési irányok. A szakiskolák szakközépiskolai osztályokat, a szakközépiskolák gimnáziumi osztályokat indítottak, a gimnáziumok igyekeztek a képzési idő növelésével „lenyúlni” a gyerekekért, és kihalászni maguk számára a sikeresebb felvételi átlagot eredményezo” „gyerekanyagot”, a képzési szerkezetben pedig szinte korlátlanul érvényesültek a szülői igények kielégítését célzó profilváltások. Mindebben komoly szerepet játszik az a hazai finanszírozási rendszerre jellemző sajátosság, hogy az intézmények forrásai függetlenek a végzettek elhelyezkedési esélyeitől.

Dél-Alföld vegyes profilú középfokú oktatási intézményei területileg nagyrészt kiegyenlítetten jöttek létre, arányuk pedig a szakképzést folytató intézmények esetében közel kétharmados volt (1. táblázat). Ott jelentek meg viszonylag kisebb számban, ahol a fenntartó tudatosan korlátozta megszerve-

1. táblázat: A tiszta és „vegyes profilú” intézmények száma és típusok közötti megoszlása Dél-Alföldön

\begin{tabular}{|c|c|c|c|c|c|}
\hline Intézménytípus & $\begin{array}{l}\text { Bács- } \\
\text { Kiskun } \\
\text { megye }\end{array}$ & $\begin{array}{l}\text { Békés } \\
\text { megye }\end{array}$ & $\begin{array}{l}\text { Csong- } \\
\text { rád } \\
\text { megye }\end{array}$ & $\begin{array}{l}\text { Dél- } \\
\text { Alföld }\end{array}$ & $\begin{array}{l}\text { Megosz- } \\
\text { lás, \% }\end{array}$ \\
\hline Szakiskola & 1 & 3 & 2 & 6 & 4,7 \\
\hline Szakközépiskola & 10 & 10 & 16 & 36 & 27,9 \\
\hline $\begin{array}{l}\text { Szakképző iskola (szakiskolai és } \\
\text { szakközépiskolai képzés) }\end{array}$ & 15 & 5 & 17 & 37 & 28,7 \\
\hline Szakiskola és gimnázium & 1 & 1 & 0 & 2 & 1,6 \\
\hline Szakközépiskola és gimnázium & 6 & 6 & 8 & 20 & 15,5 \\
\hline Szakképző iskola és gimnázium & 2 & 7 & 2 & 11 & 8,5 \\
\hline Speciális szakiskola & 3 & 1 & 0 & 4 & 3,1 \\
\hline $\begin{array}{l}\text { Egyéb (Általános Múvelődési Köz- } \\
\text { pont, pedagógiai szakszolgálat, } \\
\text { pedagógiai szakmai } \\
\text { szolgáltatások stb.) }\end{array}$ & 7 & 0 & 6 & 13 & 10,1 \\
\hline Összesen & 45 & 33 & 51 & 129 & 100,0 \\
\hline
\end{tabular}

Forrós: TelR 2008. 
zésüket, vagy hagyományosan erős szakközépiskolai rendszer volt jellemző, több felsőoktatás-orientált képzést nyújtó, nagy presztízsű iskolával, amelyek nem voltak érdekeltek gimnáziumi osztály indításában, a szakiskolák pedig a széles körű szakközépiskolai kínálat miatt csak korlátozottan léphettek az érettségit adó képzés felé (Forray, Híves 2006).

E változások nem maradtak következmények nélkül a gyakorlati képzés szervezésében sem. A szakiskolákban megjelenő szakközépiskolai képzés - a szakközépiskolák intézményi tanműhelyre támaszkodó gyakorlati képzése miatt - a teljes tanműhelyi bázis kiépítését kívánta, ami a nagyobb kihasználtság elérése végett abban vált érdekeltté, hogy a szakiskolai gyakorlati képzést is a tanműhelyben szervezze, ne pedig külső gyakorlóhelyen. A rendszerváltás utáni gyors és radikális gazdasági átalakulás lassú konszolidációja és a szakiskolai tanulók számának drámai csökkenése ugyan lényegesen javított a helyzeten, a szakiskolai tanulóknak azonban napjainkban is alig negyven százaléka vesz részt a kizárólag tanmühelyben szervezett gyakorlati foglalkozásokon (Liskó 2008). A dél-alföldi régióban végzett empirikus kutatások hasonló arányt mutatnak, fontos azonban megjegyezni, hogy az arányok hatalmas szóródása figyelhető meg a különféle intézménytípusok között, a szakközépiskolák esetében az arány közel kétszeresre nő (Velkey 2010).

A gyermekszám csökkenése ellenére így szinte egyik évről a másikra ugrásszerűen megnőtt a gimnáziumi és szakközépiskolai férőhelyek száma, ami a jellemző intézményválasztási gyakorlat miatt nemcsak a gimnáziumok és a szakközépiskolák irányába történő lényeges arányeltolódást eredményezett (1. ábra), hanem felértékelte a nagyobb városok szolgáltatásait is (Forray, Híves 2006, Varga 2008a). Vagyis a strukturális átalakulást érdemi területi átrendeződés is kísérte, ami a jelen felé közeledve a gyermekszámcsökkenés miatt élesedő verseny következtében erősödő tendenciát mutat (Vámosi 2005a).

A folyamatok strukturális értelemben legsúlyosabban a szakiskolai képzést érintették. Az érettségit nem adó szakiskolai képzésbe belépő tanulók aránya az oktatásstatisztikai évkönyv adatai szerint a rendszerváltástól napjainkig negyvennégyről huszonkét százalékra csökkent, miközben a feladatellátási helyek száma 465-ről 580-ra nőtt.

A területi átrendeződés pedig gyorsuló centralizációt mutat, a kis- és középvárosi képzési szolgáltatás lényeges szűkülése mellett a nagyobb városok és különösen a megyeszékhelyek növelték felvett tanulóik számát. Akár strukturális, akár területi okokból következik be a szakiskolai képzés iránti kereslet csökkenése, a fajlagos költségek növekedése és a képzés színvonalának csökkenése öngerjesztő folyamatot indít el a leépülő iskolákban.

A területi alapú centralizációt egyértelmủen visszaigazolják a célirányos területi vizsgálatok (Forray, Híves 2006) és a Dél-Alföldön végzett empirikus kutatások (2. ábra). A centralizáció az egyes ellátások esetében azonban eltérő mértékű. A kisebb városok a „városi imázs" alapelemének tekintik a saját 


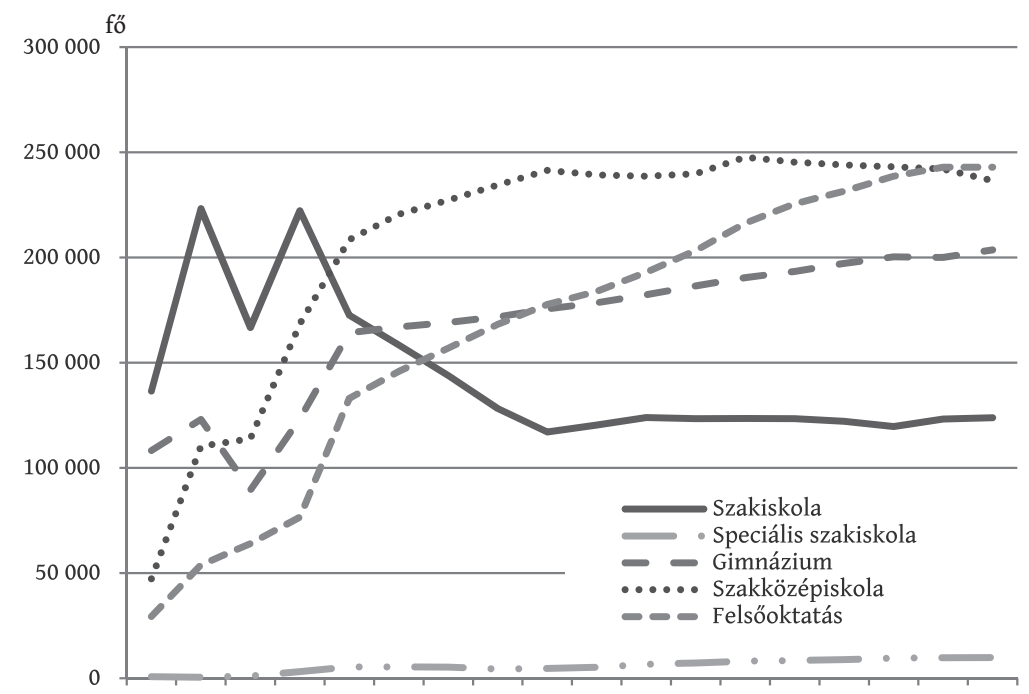

(Év) 19701980199019951996199719981999200020012002200320042005200620072008

Forrás: Okłatásstatisztikai évkönyv 2008/2009.

gimnáziumot, így erőn felüli áldozatokat is vállalnak annak megtartásáért, ezért e képzés decentralizáltabb a szakközépiskolainál. A szakiskolai képzés szintén decentralizáltabb a szakközépiskolaihoz képest, ami annak köszönhető, hogy a régió nagy hagyományú szakközépiskolái a közép- és nagyobb városokban vannak, míg a csupán szakiskolai szolgáltatást nyújtó intézmények a kisebb városokban, sőt egyes óriásfalvakban (agrárágazat) is megjelennek. Nem meglepő, hogy a legközpontosítottabb képet az érettségi utáni szakképzés mutatja, a kisebbektől a nagyobb városok felé haladva ugrásszerüen bővül a kínálat. Az adatok szerint a centralizáció mértéke a specializáltabb szakképzések és a felnőttképzés irányában tovább erősödik (Velkey 2010).

A képzési rendszer egyes szereplői azonban egyszerüen nem akarják tudomásul venni e folyamatokat, és nem igazítják a változóban lévő társadalmi igényekhez képzési szolgáltatásaikat. A megoldást ma nagyon sokan abban az irányban keresik, hogy miként lehetne ismét tanulókat gyüjteni a szakiskolákba, amit a magasabb szintü képzések kínálatának tudatos szűkítésével érnének el, többnyire a munkaerőpiac igényeire hivatkozva, amit látszólag alá is támasztanak a hiányszakmák alacsony beiskolázási arányszámai. Önmagában is releváns kérdés azonban, hogy a szolgáltatást igénybe vevők szándékaival, akaratával szemben lehet-e kényszerrel, vagyis a keresettebb képzések kapacitásainak tudatos korlátozásával az alacsonyabb presztízsű szakmák irányába visszaszorítani a tanulókat, illetve az alacsonyabb presztízsű szakmák keresettségét lehet-e piacgazdasági körülmények között bürokratikus, vagyis nem piaci eszközökkel tartósan befolyásolni. 


\section{2. ábra: A középfokú okłatás térszerkezete Dél-Alföldön}

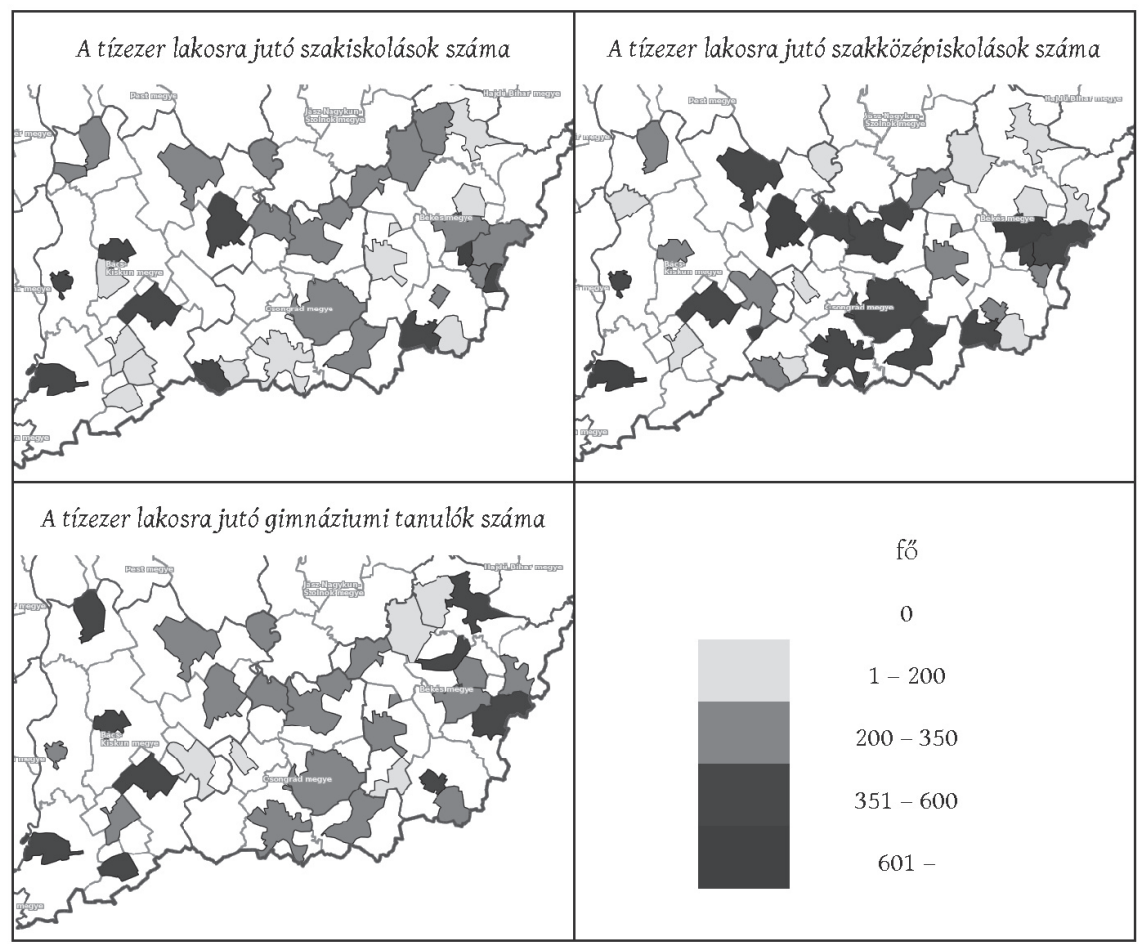

Forrás: TeIR, 2009

\section{A TISZK-modell bevezetését elóíró változtatások hatása a szakképzés szervezeti rendszerében}

A fentebb részletesen bemutatott jogszabályi változások következményeinek számbavételét azzal a kérdéssel kell kezdeni, hogy az RFKB-k miként fognak élni a valóban rendkívül széles körű jogosítványaikkal. Ennek megválaszolása előtt hangsúlyozni kell, hogy a változások ez alkalommal sem léptek túl azon a széles körben elismert fogyatékosságon, hogy a munkaerőpiac igényeinek elörejelzése - akár bürokratikus, akár tudományos alapon történik, vagyis nem automatizmusszerüen alakítja a döntéseket - legfeljebb orientálhatja, információval láthatja el a döntéshozókat, akik így továbbra is a rendszer müködését meghatározó érdekviszonyok által befolyásoltan dönthetnek csupán. Ezen az alapon legalábbis kétséges, hogy az RFKB-k felvállalják-e azt, hogy akár egyenként döntsenek a TISZK-ek konkrét beiskolázási keretszámairól.

Az RFKB-k megalakulásától napjainkig eltelt időszak egyértelmüen mutatja, hogy minden érdekelt (fenntartó önkormányzat, kamara, TISZK) igyek- 
szik jó érdekérvényesítő pozíciót szerezni, ami a fejlesztési források megszerzése végett fontos számára. Az RFKB-k összetételéből következik az új rendszernek egyik fogyatékossága is; a legfőbb finanszírozóként a források hatékony és eredményes felhasználásában érdekelt állam és a képzések közvetlen érintettjei (tanulók, szülők) nem rendelkeznek képviselettel a bizottságokban. A bizottságok összetétele alapján az sem zárható ki, hogy a szakmai alapon delegált szereplők helyi pártpolitikai megrendelések „kijáróivá” válnak. Mártonfi ezt megerősítve a politikai befolyás szakmaiságot korlátozó közvetlen hatásait elemzi (Mártonfi 2009). A bizottságok munkájában a döntések határozottságát illetően inkább a megengedő keretszabályozás és orientálás jellemző, mint a tudatos, koncepción alapuló irányítás (Garai 2007, Mártonfi 2009, Mészárosné 2010, Velkey 2010). A beépített közvetett szabályozók (pályakövetési rendszer, hiány- és támogatott szakmák listája) pedig nem képesek megváltoztatni az érdekviszonyokat, legfeljebb néhány (fontos) szempont figyelembevételét erősítik (Kerékgyártó 2010).

A szabályozás legkeményebb eleme az ezerötszáz fős létszámhatár életbelépése. A pályázati forrásokhoz és a fejlesztési támogatáshoz történő hozzájutás a szereplőket egyértelműen érdekeltté teszi az együttműködésben, amit legegyszerübben a szakképzés-szervezési társulás (társaság) formájában valósíthatnak meg. A társulási vagy társasági szervezeti forma az RFKB puha döntései esetén mindössze annyi változást jelent, hogy formálisan rá kell bólintania minden intézmény beiskolázási tervére. Ha a társulás a fenntartó intézményeinek együttmúködéseként jön létre, akkor gyakorlatilag nincs változás, csupán létre kell hozni a formális szervezetet. A tartalmi változatlanság továbbvitelére lehetőséget teremt a szakképző intézmények összevonásával létrehozott, új, „integrált” intézményi TISZK is. E modell azon fenntartók számára tűnhet kedvezőnek, amelyek több szakképző intézményt is fenntartanak (megyei jogú város, megyei önkormányzat), hiszen így a fenntartói döntési jogok (az RFKB döntésein kívül) az önkormányzatnál maradnak, ráadásul az összevonással szinte automatikusan együtt jár bizonyos (igazgatási, adminisztrációs) költségek megtakarítása, és az általában konfliktusokat eredményező belső racionalizálási kényszerek is továbbtolhatók az intézményi szintre. ${ }^{12}$ Abban az esetben, ha egy fenntartó (általában kisebb város) szakképző intézményeinek tanulói létszáma együttesen nem éri el az ezerötszáz föt, kénytelen más fenntartókkal is szövetkezni, és miután a létrejött társulások, társaságok is köthetnek megállapodásokat, a TISZK-ek e szervezetek együttműködését biztosítandó egyfajta „kvázi-ernyőszervezetként” is működtethetők.

A dél-alföldi régióban a fentebb sorolt minden szerveződéstípus megtalálható (Mészárosné 2010). Létezik olyan város, ahol néhány intézményt összevontak, más intézményeik pedig szakképzés-szervezési társulást hoztak létre. Vannak olyan társulások, amelyek a szükséges létszámhatárt zenemüvészeti, vagy évek óta szakképző évfolyamon képzést sem folytató, közgazda- 
sági szakközépiskolának nevezett kvázigimnáziummal érték el. Létezik olyan társaság, ahol három közbülső várost átugorva egy nagyobb város alapítványi képzésével hozzák össze a kívánt létszámot. Más esetben országosan hálózatként üzemeltetett ágazati TISZK jött létre. Találkozhatunk egymástól távol lévő (fizikailag racionalizálhatatlan) intézmények egy kváziintézménybe történő összevonásával, valamint húsz intézményt tömörítő nonprofit gazdasági társasági formát felvevő „ernyőszervezettel”. Sorozatban láthatunk példákat arra is, hogy az első Nemzeti fejlesztési tervben évekkel ezelőtt elindított, valóban térségi és valóban integrált szakképző központként született, több fenntartó (például megyei önkormányzat, megyei jogú városi önkormányzat) együttműködésének eredményeként létrejött szerveződések estek szét két-három, területi szempontból racionálisan nem indokolható, a fenntartók együttműködését, összefogását immár nem megkövetelö, törvényességi szempontból azonban kifogástalan szerveződésre. A dél-alföldi régió TISZK-jeit bemutató 3. ábra jól szemlélteti a létrejött szerveződések irracionális területi rendszerét.

A jogszabályok által felkínált szabadság tehát egyszerre eredményezte a szervezeti formák anarchiáját és - az új szervezeti formák álcája mögött - a

\section{3. ábra: A térségi integrált szakképző központok szerkezete Dél-Alföldön, 2011}

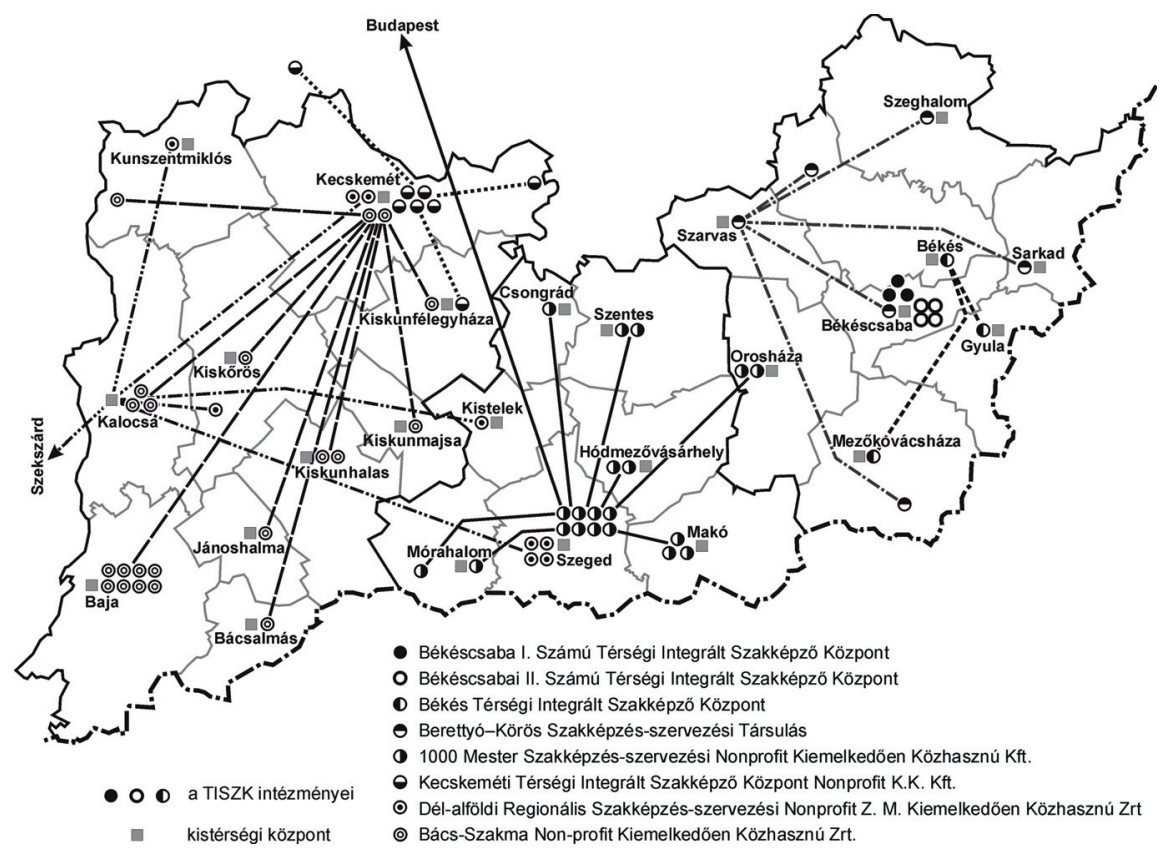

Forrás: NSZFI 2011. 
korábbi struktúrák továbbélését. Miután az alapvető érdekeltség nem változott, intézményi oldalról továbbra is a tanulók megszerzése, megtartása valamint az intézmény létének, foglalkoztatási szerepének megőrzése, a fenntartó oldaláról pedig a költségek korlátozása és a hangos balhék elkerülése a fö döntési szempont.

Az érdekeltségi mechanizmusok szinte változatlan formában történő továbbélése a területi összehangolás esélyét is alapvetően korlátozza. A megyei közoktatási és a regionális szakképzési fejlesztési tervek a területi összehangolás szándékának még a kimondását sem vállalják fel (korábban sem vállalták), a szabályozás pedig egyetlen szereplő számára sem ad jogosítványokat annak kikényszerítésére. A formálissá váló és a mindenkori érdekek szerint módosítgatott megyei és regionális tervek mellett tehát szabadon érvényesülhetnek a korábbiakban részletesen leírt intézményi és fenntartói érdekek.

Fontos kérdés még, hogy a fejlesztési támogatás fenntartón keresztül történő fogadása mennyiben változtatta meg a korábbi gyakorlatot. A Dél-Alföldön folytatott empirikus kutatás során megkeresett intézményvezetők kivétel nélkül azt a véleményt fogalmazták meg, hogy az új eljárás a lényegen nem változtatott, csupán bonyolultabb, bürokratikusabb és hosszadalmasabb lett az eljárás. Ez az egyöntetű vélemény egyúttal felhívja a figyelmet az érintettek azon szándékára is, hogy a lehető legkisebb módosítással szeretnék továbbvinni a korábbi megszokott gyakorlatot. Ez abból a jogos észrevételből következik, hogy a fejlesztési támogatás nyújtásának és fogadásának érdekviszonyaiban sem történt változtatás. Az intézmény továbbra is a források minél nagyobb arányának megszerzésében érdekelt. A fenntartó pedig továbbra is arra törekszik, hogy az így bevonható többletforrás révén csökkenjen az intézmények önkormányzati költségvetést terhelő finanszírozási kényszere. A forrásgyüjtésben sem felkészültsége, sem kapcsolatai révén nem tud a közvetlen érdekeltséggel rendelkező intézményvezető helyébe lépni, legfeljebb segíteni tudja a folyamatot, amit a körültekintően eljáró helyi vezetők korábban is megtettek már. Az intézmények által összegyüjtött források volumenét pedig nem kockáztathatja a fenntartó a valódi újraelosztás felvetésével. A változtatás a gazdasági szereplők számára egyszerủen bonyolultabb eljárást jelent, ami legfeljebb növeli érdekeik érvényesítésének kockázatait (Velkey 2010).

\section{Javaslatok a középfokú oktatás és iskolarendszerú szakképzés továbbfejlesztésére}

A TISZK-modell bevezetésének kudarca tehát összefoglalóan négy okra vezethető vissza:

1. A TISZK-ek szervezésében és létrehozásában nem fogalmazódtak meg szigorú eloírások, a lehető legnagyobb szabadsággal hozhatók létre e szerveződések, ami szervezeti anarchiához vezetett. 
2. A meghatározott ezerötszáz fős létszámhatár egyrészt tartalmában (ki számít bele) nem pontosan rögzített, másrészt könnyedén kijátszható, harmadrészt nem eredményezi a tanulók érdemi akkumulációját a szakképző szakaszban, így nem oldja a szétaprózottságot.

3. Bár az RFKB-k kimondottan erős jogosítványokat kaptak a szakképzés regionális irányítására és fejlesztésére - sőt akár egyes TISZK-ek vagy intézményegységeik szabályozására -, azonban nem élnek ezekkel a jogosítványokkal, a szakmai szempontoktól idegen politikai és a helyi érdekek uralják a bizottságok munkáját.

4. A fejlesztési támogatás és a pályázati források elosztásának rendszerén kívüli szereplők (tanuló, szülő, intézmény, gazdasági szervezet, kamara, fenntartó) érdekeltségét befolyásoló elemek egyike sem változott, így továbbra is jellemző a szakképzés megkezdése előtti átjárhatóságot korlátozó visszacsempészett párhuzamos képzésszervezés, a finanszírozási rendszer változatlansága továbbra sem bünteti a munkaerő-piaci igényekkel igazolhatatlan képzéseket, a gyakorlati képzésben (különösen az érettségi után) továbbra is meghatározó a tanmühelyi képzés.

A feltárt problémák, zavarok kezelését nagyban segítenék a követkő beavatkozások:

- A rendszer továbbfejlesztésének kulcskérdése a valódi pályaválasztásnak a szakképzés megkezdéséhez történő feltolása, ami azonnali intézkedést követel, hogy a közismereti szakaszban valóban csak szakmai orientáció és pályaválasztást megalapozó képzés történhessen. Ezzel nyílik meg ugyanis a lehetőség a szakképzési szakasz megkezdése előtti széles körü átjárhatóságra és valódi választásra.

- A szakiskolák közismereti képző szakaszára jellemző negatív szelekció korlátozása érdekében el kell érni, hogy a tanulók az általános iskola elvégzése után csak érettségit (is) adó középiskola közismereti képzésébe léphessenek be. Azon tanulók számára, akikről tizenhat éves korukra (a középiskola első éve után, vagy többszöri évismétlés miatt alacsonyabb évfolyamon) egyértelművé válik, hogy minden szakmai segítség és fejlesztés ellenére sem képesek az érettségi megszerzésére, biztosítani kell a szakképzésbe való átlépés lehetőségét. Ezzel lényegében értelmét veszti az úgynevezett előrehozott szakképzés.

- Az általános iskola elvégzése után bizonyosan megmaradó intézményválasztás (gimnázium, szakközépiskola, speciális szakiskola) megalapozása és a negatív szelekció miatt fel kell gyorsítani az általános iskola ötödik-nyolcadik évfolyamán folyó oktatás tartalmi megújítását, lényegesen megalapozottabbá téve magát a választást. A gimnázium továbbra is felsőoktatás-orientált képzést kínálna, a szakközépiskola ezzel szemben a hangsúlyt a gyakorlatorientált képzésre helyezné, ahol kiemelten kezelnék a széles körű szakmai orientációt és a pályaválasztás megalapozását. 
- A feladatellátási kötelezettség szabályozásában egyértelművé kell tenni, hogy a szolgáltatást minden érintett számára lakóhelyének térségében (városkörnyék) kell biztosítani, a területi összehangolás érdekében pedig a feladatot egyértelműen a területi önkormányzatokhoz kell telepíteni. Azon szakközépiskolai tanulók számára, akik a végzés előtti utolsó két évben a felsőoktatási felvételihez kapcsolódó emelt képzésekben nem vesznek részt, azok időtartamára gazdálkodással, vállalkozással, foglalkoztatással, adózással, hivatali eljárásokkal, szerződéses kapcsolatokkal, közigazgatással kapcsolatos legfontosabb jogi és számviteli ismeretek oktatására és a gyakorlati tevékenységre koncentráló előkészítést kell biztosítani.

- A „szakmai vizsgára felkészítő iskola” fogalmára alapozva és a szakképzés-szervezési társulás (társaság) logikáját követve a szakképzést kizárólag e tevékenységet folytató szakiskolák végeznék. Ezek fizikai bázisa a központi képzőhely (mühely), a TISZK-modellnek megfelelően széles szakmacsoportot átfogó, egyre kevésbé szétaprózódott, fizikailag is centralizált, a csúcstechnológiát felvonultató, központi fekvésü létesítmény lenne. A létrejött TISZK-eket a területi elv határozott érvényesítésével és az „egy területi egység - egy széles profilú TISZK” logika mentén újra kell rendezni. A törvényben szereplő ezerötszáz fős létszámhatár - miután abba a közismereti képzésben részt vevő tanulók is beszámítanak - könnyedén összejön három átlagos méretű vagy két nagyobb szakképző iskolából, ami nem elegendő a célként kitűzött koncentráció eléréséhez. A létszámhatárt tehát lényegesen meg kell emelni. A központi képzőhely legyen a szakmai képzés fizikai bázisa, ami köré szakképzés-szervezési társulás (társaság) formájában kapcsolódik a földrajzi értelemben is egy egységbe tartozó szakközépiskolák hálózata. Csak ez a teljes rendszer együtt alkothat egy TISZK-et, amit létszámával és területi határaival együtt kellene minden egyes TISZK vonatkozásában jóváhagynia az illetékes RFKB-nak. A társuláshoz csatlakozhatnak a térség gimnáziumai is, de azok tanulói nem számítanak bele a rögzített létszámba.

- A szakközépiskolák tanulói érettségi után vagy azt megelőzően is beléphetnek a fizikailag is a központi képzőhelyen szervezett szakképzésbe (ami több telephelyen is müködhet). A TISZK-hez tartozó szakközépiskolákban folyó szakmai orientációt és pályaválasztást megalapozó képzéseket a lehető legszélesebb kínálat felmutatásával a központi képzőhely bázisán annak szakemberei végeznék. Szintén a központi képzőhely által szerveződne a mindenki számára kötelező nyári üzemi gyakorlat. A TISZK keretében a központi képzőhely (szakiskola) által szervezett szakközépiskolák (és tanulóik) számára nyújtott szolgáltatások finanszírozása a TISZK által történne, amelynek fedezetét állami normatíva biztosítaná. 
- Az érettségit adó képzések a mérethatékonyság, a szükséges szakembergárda és az infrastruktúra alapján a kis- és középvárosok szintjén racionálisan megszervezhetők, aminek nagyon fontos pozitív következményei lehetnének e városok helyi társadalmában. A szorosan vett szakképzés ezzel szemben a nagyobb városokban és a megyeszékhelyeken koncentrálódna. A földrajzi fekvéstől függően a központi képzőhelyen (műhelyben) szervezett képzési elemek heti rendszerességgel, illetve tömbösítve is megszervezhetők.

A javasolt változtatások a strukturális hatásokon túl az egyre centralizáltabbá váló középfokú oktatás közismereti képzéseit visszaviszik a kis- és középvárosokba, ezzel nagyban erősítik e városok központi szolgáltató szerepét, munkahelyeket teremtenek, az értelmiség helyben tartásával segítik a lokális társadalmat, az intézményi infrastruktúra helyi közösségi kihasználásával pedig a közösségi, közművelődési, szociális, felnőttképzési feladatok magasabb szintű ellátását teszik lehetővé. A középiskolák decentralizációja a megyeszékhelyről e városokba vezeti vissza az ott és a környező községekben élő tizenéves fiatalok jelentős részét, vagyis a helyi szolgáltatók számára fogyasztókat, a helyi kereskedelem számára vásárlókat teremt, erősíti a diákok lokális (családi) kötődését, a társadalmi kohéziót, és csökkenti az elvándorlást. A vázolt javaslatok a területi lépték és komplex szolgáltatások tekintetében nagyon hasonlók a művelődési városközpont koncepciójához (Kozma 2002). A javaslatok e koncepciótól annyiban térnek el, hogy csak a középiskola közismereti képzésére vonatkoznak, illetve annyiban mások, hogy a középiskolák összehangolt kistérségi hálózata nyúitja magát a komplex szolgáltatást. A szakképző szakasz szervezése, a gazdaság térbeli átalakítása, a munkaerő-piaci kapcsolatok erősítése, valamint a szakmai és forrásfelhasználási (nemcsak költségvetési) szempontból hatékony szervezés - vagyis a képzés társadalmi beágyazottságának biztosítása - nagyobb területi egységeket átfogó összehangolást kíván. Ezt az összehangolást a középiskolákat (gimnáziumokat és szakközépiskolákat) hálózatba szervező TISZK-ek végeznék, immár nem a középiskolák közötti, gyermekekért folyó versenyt, hanem az együttműködést előtérbe állítva. Ez a jövőkép szorosan egybecseng a „tanuló város, tanuló régió" programban megfogalmazottakkal (Rutten, Bakkers, Boekema 2000) és az annak hazai adaptációját szorgalmazó tanulmányokkal (például Balázs 2007), és egybecseng a gazdasági hálózatok területi alapú fejlesztésének szemléletével is.

\section{Köszönetnyilvánítás}

A tanulmány kutatási hátterét a szerző által vezetett OFA K/2007 Munkaügyi tárgyú kutatások 7341/11 számú pályázat (lezárva és elfogadva a 2009/211. sz. OFA-elnöki határozattal) adja, mely vizsgálat a dél-alföldi régió példáján elemezte a szakképzés szervezeti rendszerének változásait. 


\section{Jegyzetek}

1 A 2007. évi LXXXVII. Tv. A közoktatásról szóló 1993. évi LXXIX törvény módosításáról, a 2007. évi CII. Törvény a szak- és felnőttképzést érintő reformprogram végrehajtásához szükséges törvények módosításáról, a 16/2008. (IV. 30.) OKM-rendelet a nevelési-oktatási intézmények működéséről szóló 11/1994. (VI. 8.) MKM-rendelet módosításáról és a 13/2008. (VII. 22.) SZMM-rendelet a szakképzési hozzájárulásról és a képzés fejlesztésének támogatásáról szóló 2003. évi LXXXVI. törvény végrehajtásáról.

2 Ez létrejöhet egy iskolából, vagy több intézmény összevonásával (a ma divatos szóhasználat szerint integrációjával). Az intézmény mindkét esetben müködhet több telephellyel is. A szabályozás nem fogalmaz meg kikötést a TISZK fenntartójára vonatkozóan, vagyis az lehet helyi önkormányzat, önkormányzati társulás, költségvetési szerv, kisebbségi önkormányzat, egyház, gazdasági szervezet, kamara stb.

3 Ha az együttműködésben részt vevő szervezetek önkormányzatok, akkor szakképzés-szervezési társulásról, ha nemcsak önkormányzatok, hanem alapítványok, gazdasági társaságok, egyéb fenntartók is részt vesznek benne, akkor pedig szakképzés-szervezési társaságról beszélünk (nonprofit gazdasági társaság).

4 A 2007. évi LXXXVII. tv. 9. \$-a építette be ezeket a rendelkezéseket a közoktatási törvény (1993. évi LXXIX. tv.) 67. § (5) bekezdéseként.

5 A 2007. évi CII. tv. $33 . \S$ módosította és kiegészítette a szakképzési hozzájárulási tv. (1993. évi LXXVI. tv.) 2. és 4.\$-át.

6 Az egységes iskola a „comprehensive school” modelljét próbálta hazánkban is meghonosítani. Ennek lényege, hogy a tanulók képességek, adottságok, majd képzési irányok szerinti szelekcióját nem intézményközi mozgással, hanem az intézményen belül képzési csoportok elkülönítésével oldják meg.

7 A közoktatási törvény 1996-os módosítása a művészeti képzésben direkt módon hozta vissza a párhuzamos képzésszervezést, amivel a törvény a művészeti képzést lényegében speciális szakképzéssé minősítette. Ez helyes és indokolt, ugyanakkor ezt tovább kellett volna vinni például a szakképző intézmények TISZK-ekbe szervezését előíró jogszabályi változtatások során is.

8 Az eltérő évszámok a szakmunkásképzéshez, a szakközépiskolához, illetve a szakiskolai és érettségi utáni szakképzéshez kapcsolódnak.

9 A tankötelezettség életkorának csökkentése ezzel ellentétes irányú változtatás.

10 A szocialista nagyipar felszámolódása, a magánosítás és a piaci szemlélet térnyerése következtében ez szinte minden ágazatban bekövetkezett részben vagy egészben (Liskó 2002), legfeljebb ott nem, ahol a szocialista nagyvállalat állami vállalat formájában változatlanul továbbélt (például MÁV, Volán, városi közlekedési vállalatok), mint ahogy a korábban ktsz-ekbe tömörült kvázi „maszek” formáról egyéni vállalkozásra, kisvállalkozásra váltó szolgáltatóknál sem (fodrász, kozmetikus, cipész, bőrdíszműves, fotós, egyes javító-, szerelőszakmák).

11 A jogszabályi változtatások utáni intézményátszervezési hullám 2008-ban indult el, így a táblázat a TISZK-ek létrehozása előtti legfrissebb adatokat tartalmazza.

12 Emellett szinte minden ilyen döntés mögött ott található a konkurens politikai szereplők által támogatott, vagy hozzájuk tartozónak vélt, más módon csak nagyon nehezen leváltható intézményvezetőtől való megszabadulás szándéka is. 


\section{Irodalom}

Archer, M. S. (1988): Az oktatási rendszerek expanziója. Iskolamester, 4. Oktatáskutató Intézet, Budapest

Balázs É. (2007): A versenyképesség területi és társadalmi összefüggései. In: Simon M., Kósa B. (szerk.): Közoktatás és versenyképesség. Hatékonyság és minőség: aktuális kérdések a hazai közoktatásban. Oktatáskutató és Fejlesztő Intézet, Budapest, 29-43.

Balázs É., Palotás Z. (2006): A közoktatás irányítása. In: Halász G., Lannert J. (szerk.): Jelentés a magyar közoktatásról 2006. Országos Közoktatási Intézet, Budapest, 55-104.

Báthory Z. (2000): Tanulók, iskolák - különbségek. Egy differenciális tanításelmélet vázlata. OKKER Oktatási Kiadó, Budapest

Benedek A. (2003): Változó szakképzés. A magyar szakképzés szerkezetének változásai a XX. század utolsó negyedében. OKKER, Budapest

Csapó B. (2008a): A közoktatás második szakasza és az érettségi vizsga. In: Fazekas K., Köllő J., Varga J. (szerk.): Zöld könyv a magyar közoktatás megújitásáért. ECOSTAT, Budapest, 71-94.

Csapó B. (2008b): A magyar iskolarendszer adaptációs problémái. A tudás minősége. In: Fazekas K. (szerk.): Közoktatás, iskolai tudás és munkapiaci siker. MTA Közgazdaságtudományi Intézet, Budapest, 113-130.

Forray R. K., Híves T. (2006): A szakképzés szerkezete az országos kistérségekben. Szakképzési Szemle 1., 7-25.

Garai P. (2007): A szakképzés munkaerő-piaci szemléletű fejlesztése. Szakképzési Szemle, 1., 48-62.

Hermann Z. (2008): Hogyan értelmezzük az iskolarendszer minőségi mutatóit nemzetközi összehasonlításban? In: Fazekas K. (szerk.): Közoktatás, iskolai tudás és munkapiaci siker. MTA Közgazdaságtudományi Intézet, Budapest, 43-72.

Kerékgyártó L. (2010): A szakiskolai 9. és 10. évfolyamok fejlődéséről. Szakképzési Szemle, 2., 19-37.

Kézdi G. (2008): Nem csupán a rendszerváltás következménye. A szakiskolai képzés hanyatló hozadékai mögött álló okok Magyarországon. In: Fazekas K. (szerk.): Közoktatás, iskolai tudás és munkapiaci siker. MTA Közgazdaságtudományi Intézet, Budapest, 73-96.

Kozma T. (2002): Határokon innen és határokon túl. Regionális változások az oktatásügyben, 1990-2000. Oktatáskutató Intézet, Új Mandátum Könyvkiadó, Budapest

Liskó I. (2008): Szakképzés és lemorzsolódás. In: Fazekas K., Köllő J., Varga J. (szerk.): Zöld könyv a magyar közoktatás megújitásáért. ECOSTAT, Budapest, 95-120.

Loránd F. (1994): Egy épülő komprehenzív iskolamodellről. Iskolakultúra, 4., 23-24.

Martonfi Gy. (2009): A TISZK-rendszer kiépülése 2007-2008-ban. Szakképzési Szemle, 4., 403-433.

Mészárosné Sz. A. (szerk.) (2010): A Dél-alföldi Régióban müködő TISZK-ek, illetve TISZK-ekhez kapcsolódó gyakorlati képzóhelyek képzési kapacitásainak vizsgálata 2007-2009 között. Készült a Dél-alföldi RFKB megbízásából a Dél-alföldi Oktatási Hivatal megrendelésében (kézirat)

Pálné Kovács I. (2008): Helyi kormányzás Magyarországon. Dialóg Campus Kiadó, Budapest-Pécs

Rutten, R., Bakkers, S., Boekema, F. (2000): The analysis of learning regions: Conclusions and research adenda. In: Boekema, M., Bakkers, R. (eds.): Knowledge, innovation and economic growth. Cheltenham, UK, Northampton, USA

Varga J. (2008a): Az iskolaügy intézményrendszere, finanszírozása. In: Fazekas K., Köllő J., Varga J. (szerk.): Zöld könyv a magyar közoktatás megújitáááért. ECOSTAT, Budapest, 235-259.

Varga J. (2008b): Szakképzés. In: Nagy Gy. (szerk.): Jóléti ellátások, szakképzés és munkakínálat. MTA KTI, Budapest, 9-31.

Vámosi T. (2005a): A szakképzési rendszer területi problémái. Humánpolitikai Szemle, 1., 49-58.

Vámosi T. (2005b): Hátrányos helyzet újratermelődése a szakképzés rendszerében. Szakoktatás, 7., 23-26.

Velkey G. (2010): Az oktatás hazai rendszere, múködési zavarai és megújitásának irányai (A szakképzési hozzájárulás és a szakképzési alaprész felhasználásának területi és strukturális jellemzői, a szabályozás változásának következményei és továbbfejlesztésének javasolt irányai). OFA, Budapest, 59-72. Foglalkoztatást elősegítő munkaügyi kutatások (OFA Kutatási évkönyv 5.) 